\title{
Newspapers and Authorities in Seventeenth-Century Germany
}

\author{
Jan Hillgärtner
}

After the first newspaper was established in Strasbourg in 1605, printers across the Holy Roman Empire, pursuing financial profit, were quick to jump on the bandwagon of the new medium. ${ }^{1}$ It was not uncommon for several printers in one city simultaneously to set up a newspaper of their own; a situation that often led to assiduous legal battles between printers, local authorities and occasionally even the Habsburg administration in Vienna. Sometimes, such legal battles led to a ban. In Frankfurt, for example, the Imperial postmaster-turned-newspaper publisher Johann von den Birghden successfully demanded a ban of the Diarium Hebdomadale, a periodical started by Thomas Schönwetter in 1620 that threatened von den Birghden's local monopoly in Frankfurt. ${ }^{2}$ Though many such disputes were waged, however, remarkably few led to similar results, ending the existence of a title. By and large, throughout the empire, authorities were surprisingly tolerant toward sensational, biased or downright wrong reporting, and cases that led to the ban of a title, such as von den Birghden vs Schönwetter, were remarkably rare.

Preventive censorship, the most effective measure to prevent the distribution of unwelcome information, was only practiced in Stuttgart, where John Frederick, Duke of Württemberg employed his royal librarian and archivist Johann Jakob Gabelkover as corrector of the newspaper. ${ }^{3}$ Elsewhere, political elites did little more than protest after a message had already been distributed. Yet such cases, too are sparse. In general, authorities in the Holy Roman Empire appeared not to meddle in the business of newspapers unless they were prompted to by outside forces, such as foreign powers or rivalling

1 Johannes Weber, 'Straßburg 1605. Die Geburt der Zeitung', Jahrbuch für Kommunikationsgeschichte, 7 (2005), pp. 3-26.

2 Wolfgang Behringer, Im Zeichen des Merkur. Reichspost und Kommunikationstevolution in der Frühen Neuzeit (Göttingen: Vandenhoeck \& Ruprecht, 2003), pp. 386-387.

3 For a description of the editorial practices in the Zeittungen, see Johannes Weber, 'Kontrollmechanismen im deutschen Zeitungswesen des 17. Jahrhunderts. Ein kleiner Beitrag zur Geschichte der Zensur', Jahrbuch für Kommunikationsgeschichte, 6 (2004), pp. 56-73. 
authorities. ${ }^{4}$ This was also the case with von den Birghden, who had complained about his competitor's newspaper directly to Emperor Ferdinand II, thus forcing the issue.

Most scholarship devoted to the interplay between rulers and periodicals in Germany tends to emphasise their oppositional relationship, on the assumption that periodicals posed a threat to the arcane sphere of policymaking and demanded scrutiny. ${ }^{5}$ As Johannes Weber has pointed out, however, the liberal if not lax attitudes towards newspapers on the part of the nobility problematises that point of departure. ${ }^{6}$ Self-censorship, guided by newspaper publishers' keen sense of the boundaries maintained by local elites, may help to understand this tension. Privileges were another way for authorities to control the content of the newspapers without requiring preventive censorship. Yet privileges worked only on a local level; imperial privileges were almost impossible to manage, because the Emperor relied on local cooperation to enforce his conditions. Thus when the Breslau printer Georg Baumann obtained an imperial privilege for his newspaper in 1629 , he was cautioned by the imperial administrator that it 'should be subject to censorship either by the council or an imperial magistrate. ${ }^{7}$ However, when an imperial letter of 20 April 1639 instructed the city council of Breslau to 'stop the trade [and publication] of newspapers and other infamous works and editions', this did little to stop the publication of newspapers in the city. ${ }^{8}$ Whereas the strong and legally binding

4 The same was true in the Dutch Republic where the authorities largely steered clear of the newspapers business. Indeed, it is noteworthy that in the Dutch Republic, the circulation of English newspapers and the portrayal of Dutch authorities in the eighteenth century appears to have caused more concern in the political sphere than Dutch-language periodicals printed at home and their reporting. See Jeremy Black, 'The United Provinces and the British Press, 1725-37: Newspaper Abuse and Diplomatic Complaints', Quaerendo, 17:2 (1987), pp. 128-136. See also: Joop Koopmans, 'Dutch Censorship in Relation to Foreign Contacts (1581-1795)', in Joop Koopmans, Early Modern Media and the News in Europe. Perspectives from the Dutch Angle (Leiden/Boston: Brill 2018), pp. 282-302.

5 Jürgen Wilke, 'Pressezensur im Alten Reich', in Jürgen Wilke (ed.), Massenmedien und Journalismus in Geschichte und Gesellschaft. Gesammelte Studien (Bremen: Edition Lumière, 2009), pp. 77-92; Elger Blühm and Rolf Engelsing, Die Zeitung. Deutsche Urteile und Dokumente von den Anfängen bis zur Gegenwart (Bremen: Carl Schünemann Verlag, 1967).

6 Weber, 'Kontrollmechanismen im deutschen Zeitungswesen', pp. 56-73.

7 'von der Kammer oder einem kaiserlichen Rathe Censur geübt werden [sollte]'. Quote taken from Weber, 'Kontrollmechanismen im deutschen Zeitungswesen', pp. 13-14. Translations are my own unless stated otherwise.

8 '[Die] Krämerei mit Zeitungen und solchen famos Schriften und Traktaten gänzlich [verbieten]', cited after Willy Klawitter, 'Aus der Frühzeit der schlesischen Zeitungen', Zeitschrift für Ostforschung, 3 (1954), p. 78. No issues of Baumann's newspaper have survived. The first surviving newspaper printed in Breslau was the Neu einlauffende Nachricht von Kriegs- und Welt-Händeln, printed by Gottfried Jonisch in 1665 and then again from 1690 to 1700 . It is 
condemnation of Schönwetter in Frankfurt resulted in the ban of his newspaper, this was not the case elsewhere.

This article suggests a wholly different perspective is required to fully understand the relationship between rulers and the early newspaper. By analysing two cases in which the rulers sought not to stifle reporting or ban a periodical but employ the new media genre for their own purposes, it shows that rather than oppositional forces, German newspapers could also be instruments of power, as they were to be in France. ${ }^{9}$ This argument has severe implications for our understanding of the rise of the newspaper. Historians of the press tend to link the emergence of the newspaper and the proliferation of the new genre to economic reasons: printers and publishers understood that the audience's desire, if not curiosity, to read about the latest events could be addressed with a product such as the newspaper. ${ }^{10}$ I will argue, however, that political reasons were just as important and that some rulers understood that they could exert control over their subjects through the newspaper and use the new medium to shape a positive image of themselves and their policies. As we shall see, Emperor Ferdinand II was amongst those who embraced this opportunity.

\section{Communicating the Official Standpoint: The Ordentliche Postzeittungen}

In 1622, the Vienna printer Matthäus Formica published a new newspaper: the Ordentliche Postzeittungen. ${ }^{11}$ Karl Holter was the first to observe that this periodical, Formica's second, was devoted entirely to reports from the court

likely that a newspaper was printed in Breslau prior to 1665 as Gottfried's son Christopher Jonisch requested a newspaper privilege in a second petition in 1650.

9 For the Dutch case see Helmer Helmers, 'Foreign News in Times of Domestic Crisis: the Truce Conflicts, the Thirty Years' War and the Rise of the Dutch Newspaper', in Alexander Wilkinson and Graeme Kemp (eds.), Negotiating Conflict and Controversy in the Early Modern Book World (Leiden/Boston: Brill, 2019), pp. 253-268. For France, see Stéphane Haffemayer, L'information dans la France du XVII ${ }^{e}$ siècle. La Gazette de Renaudot de 1647 à 1663 (Paris: Honoré Champion, 2002).

10 Johannes Weber, 'Der große Krieg und die frühe Zeitung: Gestalt und Entwicklung der deutschen Nachrichtenpresse in der ersten Hälfte des 17. Jahrhunderts', Jahrbuch für Kommunikationsgeschichte, 1 (1999), pp. 23-61.

11 The earliest surviving issues date from 1623 but we can safely assume that the periodical was already in circulation two years prior to that. See Jan Hillgärtner The German Newspaper 1605-1650. A Bibliography (Leiden/Boston: Brill, forthcoming). 
in Vienna and that it might have been actively supported by Ferdinand II. ${ }^{12}$ Unlike other European newspapers at this time, with their haphazard reporting stemming from all corners of Europe, the Ordentliche Postzeittungen reported exclusively on domestic news: matters from Vienna and its environs. This section will analyse the contents of this extraordinary newspaper, showing that it was nothing less than a state newspaper.

The reporting focussed strongly on matters of importance to the Habsburg Empire, and by far the largest proportion of reporting covered the latest events from the imperial capital. News ranged from the latest occurrences at the Emperor's court down to social matters in Vienna, including crime, the development of prices and coinage, and recent news on the harvest. The reporting was strongly biased and catered to the sentiments of the Habsburg rulers. It shone a positive light on the Emperor and his court by focussing on the well-functioning administration and the power of the Emperor to influence international politics. Ferdinand II was at the centre of every report, and news typically conveyed the image of a sought-after ruler with international influence. The Ordentliche Postzeittungen listed in great detail the foreign visitors to the court; princes, diplomats and merchants alike. It also contained regular updates on the whereabouts of the Emperor whenever he left Vienna for his travels around Europe.

The Ordentliche Postzeittungen focussed on matters of importance to the Habsburg administration. The hot topic of 1621/22 was the Diet of Sopron (Ödenburg) where Emperor Ferdinand II met with the Hungarian Estates to discuss the terms of a possible Hungarian involvement in the Thirty Years War on the Habsburg side. ${ }^{13}$ Securing Hungarian support for the Habsburg cause was crucial to Ferdinand. Gabriel Bethlen, who deeply opposed Habsburg autocracy, had an efficient and well-trained standing army at hand that had already engaged the Emperor in minor skirmishes from 1619 onwards. The six surviving issues of the Ordentliche Postzeittungen for 1622, dating from late April to mid-July, devoted almost all their attention to the meeting in Sopron. As could be expected from a periodical printed right in the heart of the Habsburg Empire and under the guise of authorities, the Emperor was portrayed as the one taking initiative in the negotiations, who usually had the upper hand and dictated the topics of discussion. This put a strong spin on the

12 Karl Holter, 'Aus der Geschichte des Wiener Zeitungswesens im 17. Jahrhundert', Zeitungswissenschaft, 15 (1940), pp. 238-244.

13 Géza Pálffy and Alan Campbell, 'Crisis in the Habsburg Monarchy and Hungary, 16191622: The Hungarian Estates and Gábor Bethlen', The Hungarian Historical Review, 2:4 (2013), pp. 733-76o. 
facts, since Ferdinand actually arrived at the diet as a supplicant. Following the military successes of Bethlen in the aftermath of the Battle at White Mountain, the Prince of Transylvania was free to accept or reject the terms of a possible alliance between the Kingdom of Hungary and the Habsburg Empire. It was by no means the case that Ferdinand could dictate the terms of an agreement, let alone expect there to be a positive outcome of the diet in the form of a contract between the Hungarian estates and the Habsburg Empire.

In the Ordentliche Postzeittungen, however, the Emperor took centre stage in all reports in the surviving issues of 1622 . The newspaper highlighted Ferdinand's status by drawing attention to Bethlen's gift to the emperor. The horse in fine bridle and headgear, the newspaper stressed, was estimated at a value of 100,000 taler, and honoured the giver as well as the receiver. In fact, the diet at Sopron proved to be tough bargaining. Neither Bethlen Gabor nor the Emperor came significantly closer to their goal of winning the support of the Hungarian Estates. Ferdinand made several journeys to Sopron, softening his demands and making ever more concessions to the Estates to win their support. This, evidently, was a problem for the Ordentliche Postzeittungen. While it was impossible to avoid the topic altogether, it reduced its reporting of the Diet of Sopon to a minimum. To compensate for the lack of news, the periodical reported on festivities that had taken place at Vienna. Thus issue number $\mathrm{H}$, from May 1622, ran the story of the staged marriage of two of Ferdinand's favourite court dwarves in Vienna. The report stated that:

On 1 [May] the marriage between the two dwarves was held in the chamber of his Imperial Majesty.... The meal was held in the large hall in the presence of six pairs of giants [regular sized people] ... there were a hundred times more waiters than guests. Jonas [the dwarf] has played the constable ... and occasionally played the violin so badly that everyone had to cover their ears. The bride looked very unhappy ... yet the spectators were delighted. ${ }^{14}$

14 Den 1. Dits/ ist deß Welschen Zwergs vnd Welschen Zwergin Hochzeit bei Hof gehalten worden/ die Copulation bei Jhr: Kay: May: im Zimmer/ ... beschehen/ die Tafel war auff dem großen Saal mit 6. baar Mannß und Weibs Persohnen dergleichen Risen besetz/ der Auffwarter waren Hundertmal mehr als die zu Tisch saßen/ der Jonas hat daß Ober-Hofmaister Ampt versehen ... bald ein straiff durch die Geigen gethan/ daß man die ohren zuhalten müssen/ die Jungfraw Braut war sehr trawrig/ ... die Spectatores vnd Zuseher desto fröhlicher'. H. Ordentliche Postzeittungen (Vienna: Matthäus Formica, 1622), p. [1]. 
The prominent space in the Ordentliche Postzeittungen devoted to the dwarf marriage contrasts starkly with other German newspapers. Of the 12 different newspapers in 1622, all other newspapers largely revolved around the Diet at Sopron, and the one that mentioned the dwarf marriage devoted only one sentence to it. ${ }^{15}$ The news from Vienna reported in the other newspapers painted a considerably less rosy picture of the situation in the imperial capital in the summer months than the Ordentliche Postzeittungen did. One of the reoccurring topics was the lack of food in the city, in particular the high prices for meat, which enraged the local population. A number of newspapers printed outside Vienna reported on these calamities and mentioned the growing resentment towards the Imperial administration..$^{16}$ Ferdinand's demand to garrison troops at the Hoher Market Square was met with staunch resistance by the 'disobedient' and 'rebellious' residents, which was broken only by sheer force of arms. ${ }^{17}$ There was no place for this kind of news in the Ordentliche Postzeittungen.

To understand just how much the coverage in the Viennese newspaper differed from that of most other periodicals, it is worthwhile to take a closer look at the reporting from November and December $1632 .{ }^{18}$ Two news items dominated in German newspapers at this moment: the death of the Swedish king Gustavus Adolphus and the aftermath of the Siege of Maastricht. Gustavus Adolphus had just unexpectedly died on the battlefield in Lützen outside Leipzig on 6 November and his fate as well as the outcome of the battle and movements of Swedish and Imperial troops in Saxony were the central point of reporting. Other reports revolved around the negotiations following the capture of Maastricht. In August, the Dutch stadtholder Frederick Henry had brought the city under control of the Dutch States, which had led to a series of negotiations between the United Provinces and the Spanish Habsburgs. All periodicals of the time devoted considerable space to these two important

15 Von den Birghden's reported on the marriage in just one sentence within the digest of Viennese news in Num. XVI. Vnvergreiffliche Postzeittungen (Frankfurt: Johann von den Birghden, 1622), p. [2]. The other reports can be found in issue 16 of the Aviso Relation oder Zeitung (Wolfenbüttel: Elias Holwein, 1622).

16 Among them were Elias Holwein's Aviso Relation oder Zeitung (issues 12 and 13) and Johann von den Birghden's Frankfurter Postzeitung (issues XXV to XXVII).

17 'vngehorsam' and 'Rebellische funcken', Wöchentliche Zeitung aus mehrerley örther. Ao. 1622. No: 19 (Hamburg: Johann Meyer, 1622), p. [1].

18 For a more detailed study on the reporting around the death of Gustavus Adolphus in pamphlets and newspapers see Jan Hillgärtner, "The King is Dead. German Broadsheets Printed on the Death of Gustavus Adolphus and Charles I', in Andrew Pettegree (ed.), Broadsheets. Single-sheet Publishing in the First Age of Print (Leiden/Boston: Brill, 2017), pp. $295^{-} 315$. 
events, the Ordentliche Postzeittungen, by contrast, seemingly devoted a lot less attention to those events. ${ }^{19}$

In many ways our understanding of the function of the Ordentliche Postzeittungen is restricted by the poor survival of the periodical. ${ }^{20}$ Nevertheless, it stands to reason that beyond its propagandistic function, it also served as an official means of communication within the Habsburg Empire. On a more or less regular basis, Formica printed official decisions concerning the value of coins and weights, taxes and the set prices for food and transport. Issue Vvv of November 1623, for example, reported the devaluation of coins prominently on the first page. 'On 21 [November], the following decision has been made with regards to coins: all coins shall be valued according to the Bavarian system and a lowering of prices will take effect on 3 or 4 December .... ${ }^{21}$ This announcement was not unusual in the period, when the debasement of money served to meet the expenses of the Thirty Years War. Leading to a sharp devaluation across all of Germany, it was an important matter for anyone in the Holy Roman Empire, especially those who wished to trade with Vienna.

The Ordentliche Postzeittungen was meant to be disseminated and enjoyed a wide distribution within the Habsburg Empire. ${ }^{22}$ It regularly contained social news from Vienna at the end of each issue throughout its first years of existence. This section was populated with news of the coming and goings of

19 Due to the poor survival it is impossible to discern if the newspaper reported on these matters at all. The surviving eight issues show a more domestic focus. Even when the Emperor and his army obtained a victory, these victories received little attention in the Ordentliche Postzeittungen. For example, in issue of 20 March only six lines of text described the Imperial victory over the Swedish army at Bamberg.

20 Only 445 issues of the newspaper have come down to us from the period before 1701, representing just over eight percent of all issues of this periodical that must have been printed. The Ordentliche Postzeittungen appeared between 1622 and at least 1672, presumably without any interruption, in one weekly issue. Later, its frequency was increased to two weekly issues. Given this periodicity, we can safely assume that at least 5433 issues must have appeared in the seventeenth century. This survival rate is on the lower end, compared to other periodicals of the time, of which often twenty to fifty percent survived. 'Den 21.hat man wegen der Müntz geschlossen/ vnd wie verlaut solle so woll die Müntz als auch die Victualien und Wahren allerdings nach Bayrischer Ordnung geschetzt vnd gesetzt werden/ die Calierung solle auf den 3. oder 4. Decemb. gewiß beschehen'. Vvv. Ordentliche Postzeittungen (Vienna: Matthäus Formica, 1623), p. [1].

22 Evidence for the wide distribution of the newspaper can be gathered from the fact that copies of the Ordentliche Postzeittungen have come down to us in nineteen libraries across Europe, ranging from the British Library in London to the Russian State Archive in Moscow. This is an extraordinarily wide distribution, compared to other newspapers of the time that more often than not survive only in a handful of libraries and archives. On the distribution see the author's forthcoming The German Newspaper 1605-1650. A Bibliography. 
international dignitaries and diplomats as well as with estimations of the size of their entourage. ${ }^{23}$ The section was not visually distinguished from the other parts of reporting. It is plausible to think that Formica added this section with the intention of entertaining readers, rather than to provide straightforward reporting on political, military and economic matters.

Given the tight censorship regulations and the distribution of information in Vienna, we can safely assume that the Ordentliche Postzeittungen was subject to close scrutiny. ${ }^{24}$ Formica was the first printer of a newspaper in Vienna and had been equipped with a privilege to publish a newspaper alongside his local competitor Gregor Gelbhaar in $1615 .{ }^{25}$ The university was tasked with exercising the censorial control over the newspapers. The close connections he made with the Imperial chancellery at the very beginning of his career as a printer, when he inherited his workshop from his mother, presumably made him all the more likely to publish a periodical partial to the interests of his sponsor. His two newspapers were perhaps the first newspapers of the seventeenth century destined to disseminate the Habsburg perspective and portray the Emperor in a positive way. However, the reports chosen for inclusion did not all strictly follow the principles of sober reporting of matters concerning the upper echelons of society.

Besides its flattering picture of the court, the newspaper also offered entertainment news. Issue I 14 from March 1628 reported on the celebrations around carnival in Vienna. As part of these festivities, 'butchers dressed up as peasants' and staged a parody wedding right at the Burgplatz in the very centre of Vienna. The celebrations included a banquet that descended into chaos when plates and cutlery were thrown across the square and the butchers competed in pulling a goose. ${ }^{26}$ Such staged traditional peasant's wedding were a common feature of upper German and Austrian carnival culture and as such

23 The issue from 29 March 1625 for example reported the arrival of a Polish prince in Graz, whose travels to Vienna the newspaper would cover over the course of the following weeks.

24 On press censorship in Vienna in the seventeenth century, see Helmut W. Lang, 'Österreiche Zeitungsverlagsgeschichte im 17. Jahrhundert', in Paul Raabe (ed.), Bücher und Bibliotheken im 17. Jahrhundert in Deutschland (Hamburg: Dr. Ernst Hauswedell \& Co, 1980), pp. 137-138.

25 Norbert Bachleitner, Franz M. Eybl and Ernst Fischer (eds.), Geschichte des Buchhandels in Österreich (Wiesbaden: Harrassowitz Verlag, 2000), p. 25. It appears however that Gelbhaar did not immediately begin publishing his newspaper and that Formica and his successors remained without competition on the Viennese market for newspapers until the 1640 .

26 'Fleischhacker allhie einen Auffzug gleich einer Bawren Hochzeit gehalten', Ordentliche Zeitungen I 14 (Vienna: Matthäus Formica, 1628), p. [1]. 
not immediately a noteworthy matter. ${ }^{27}$ It seems in this case the report on the chaotic wedding was included to provide entertainment for readers from afar. Other entertainment news in the Ordentliche Postzeittungen included announcements of public festivities such as fireworks, dance performances, or horse racing. Such announcements suggest that Formica also anticipated a middle class readership in or close to Vienna.

The Ordentliche Postzeittungen was a remarkable periodical in the context of the first half of the seventeenth century in many ways. Focussing almost exclusively on Viennese and courtly matters, it was unusually biased by the standards of the time. ${ }^{28}$ Its proximity to the Habsburg court meant that its reporting was severely restricted by the imperial government. Elsewhere, printers often sought the support of their local council or administration, and it is more than likely that this was also the case for the Ordentliche Postzeittungen. It was not uncommon that they delivered a number of copies free of charge to the council in return for a privilege that banned other local printers from publishing their own newspaper. ${ }^{29}$ Such partnerships were, officially at least, limited to economic terms. Rather than being the mouthpiece of the ruler, publishers were expected to abstain from reporting local events. ${ }^{30}$ The Ordentliche

27 Parodies and staged weddings were common in Viennese and southern German carnival festivities, see Hans Schuhladen, 'Faschingshochzeiten als Spielformen', Bayerisches Jahrbuch für Volkskunde (1991), pp. 61-102.

28 See my forthcoming News in Times of Conflict. The Development of the German Newspaper, 1605-1650 (Leiden/Boston: Brill, 2021) for a discussion of partial reporting. 'Bias' and 'partiality' are difficult concepts in the context of early modern newspapers. Newspapers could be expected to contain overtly biased reports and it was not uncommon that one issue covered the same event from two very different angles. This was a safety mechanism on the part of the printers who by including all incoming reports sought preempt all possible allegations of partiality against them. See Jörg Jochen Berns, "Nochmals Zur 'Parteylichkeit'. Entstehensbedingungen, Kriterien, Geltungsbereich', in Astrid Blome and Holger Böning (eds.), Presse und Geschichte. Leistungen und Perspektiven der historischen Presseforschung (Bremen: Edition Lumière, 2008), pp. 67-75.

29 Perhaps the best studied example for the practice of trying to squeeze each other out of the market was the series of legal disputes between Johann Meyer and Hans Jakob Kleinhans in Hamburg in the 163os. See Carsten Prange, Die Zeitungen und Zeitschriften des 17. Jahrhunderts in Hamburg und Altona. Ein Beitrag zur Publizistik der Frühaufklärung (Hamburg: Christians, 1978), pp. 85-89.

30 Johannes Arndt, 'Die europäische Medienlandschaft im Barockzeitalter', in Irene Dingel and Matthias Schnettger (eds.), Auf dem Weg nach Europa. Deutungen, Visionen, Wirklichkeiten (Göttingen: Vandenhoeck \& Ruprecht, 2010), pp. 32. Printers also preemptively excluded local and domestic reporting from their periodicals. Candid or politically charged reporting could always land printers in legal troubles and avoiding local reporting was done with the intention to avoid getting into trouble with their respective local council or ruler. 
Postzeittungen was clearly based on a different kind of relationship. It is safe to assume that Formica received some form of compensation for the publication, either through direct payment, guaranteed buying of issues or indirectly through further business with the court in Vienna.

\section{Newspapers as Tools of Communication: The Aviso Relation oder Zeitung}

The Offentliche Postzeittungen, the propagandistic mouthpiece of Ferdinand II, clearly shows the value of newspaper to rulers, and thus prompts the question whether perhaps rulers also started their own newspapers. Johannes Arndt categorically rejected this possibility for the Holy Roman Empire. ${ }^{31}$ He argued this on the grounds of an analysis of the business practice of the well-known Strasbourg printer Johann Carolus, who turned his handwritten newsletter service into a printed newspaper in 1605 . Carolus was driven by an entrepreneurial spirit, eager to safeguard the economic success of his Relation aller fürnemmen und gedenckwürdigen Relationen. Carolus specifically highlighted the high costs he had incurred when he petitioned the council with the goal to obtain a privilege for his periodical that would free him from local competition. He stressed that: 'after [I] acquired the presses of Tobias Jobin, I have invested considerable capital for printing the newspaper., ${ }^{32}$ The newspaper had commercial value for him and having a local monopoly would have surely helped securing a steady income. Yet whereas the world's first newspaper may have been inspired by commercial motivations, the world's second newspaper was not. In 16og, Duke Henry Julius of Braunschweig Wolfenbüttel cooperated with Johann Adolph von Söhne to establish the Aviso Relation oder Zeitung. This newspaper served an official function for the duke's court and began his career started as a prolific printer of funeral sermons and panegyric literature. ${ }^{33}$ As his relationship with the duke evolved, he switched to official

31 Johannes Arndt, Herrschaftskontrolle durch Öffentlichkeit. Die publizistische Darstellung politischer Konflikte im Heiligen Römischen Reich 1648-1750 (Göttingen: Vandenhoek \& Ruprecht, 2013), pp. 94-95.

32 'Nach dem Ich vor dißem die Wochentlichen gewissen Avisen/ hab ich Zu etwas ergötzlichkeit des uncostens/ so ich Jährlich darfür Außlegen/ unnd Anwenden muß ... Unnd ich aber vor der Zeit/ weylandt Thobiae Jobins seligen Truckerey hoch unnd theuer an mich erkaufft', cited after Weber, 'Straßburg 1605', p. 6. I relied on the quotation provided by Weber here.

33 Christoph Reske, Die Buchdrucker des 16. und 17. Jahrhunderts im deutschen Sprachraum. Auf der Grundlage des gleichnamigen Werkes von Josef Benzing (Wiesbaden: Harrassowitz, 2007), p. 1017. 
print. His print shop existed alongside the ducal workshop ran by Johann Stange, to whom Henry Julius commissioned all of his jobs until at least 1613 . A relationship between Henry Julius and von Söhne must have already existed in 1608, since the printer was officially tasked to print the Aviso Relation oder Zeitung from the beginning of the following year. ${ }^{34}$ After this, von Söhne increasingly geared his publishing programme to the needs of the court as he started to print official documents such as edicts and proclamations.

Von Söhne had no role in editing the newspaper. He was merely commissioned to print the handwritten newsletters to which Henry Julius had a subscription. Such commercial newsletters, also known as 'avvisi', served as the main providers of news before the rise of the printed newspaper. Their prohibitive price made them unaffordable for large parts of society, however. ${ }^{35}$ Printed newspapers, distributed at a lower price than the newsletters, had a much wider potential audience. The goal of Henry Julius's commission was predominantly to speed up the dissemination of news within his duchy. In order to do so, the duke simply provided von Söhne with the weekly handwritten newsletter which the latter then printed. ${ }^{36}$ Von Söhne's newspaper, then, stood in stark contrast to both Johann Carolus's Relation and Matthias Formica's Ordentliche Postzeittungen. Carolus had no official affiliation and his income depended on how well his editions sold in Strasbourg and beyond. Formica was a propagandist for the imperial court, and may have reaped the financial benefits from that position, but he himself was responsible for the title. Von Söhne, on the other hand, was merely the printer of an aviso edited elsewhere, presumably in Augsburg.

This arrangement has important implications for the way in which we should envisage the circulation of news in the duchy. The handwritten newsletters which Söhne printed had circulated at court. Thus, when the printed issue of Aviso Relation oder Zeitung appeared, the Duke's inner circle already

34 It was a curious decision of the duke to turn to von Söhne to publish the newspaper rather than to rely on the service of Stange. The reasons behind this decision are yet to be established.

35 Mario Infelise, 'From Merchants' Letters to Handwritten Political Avvisi: Notes on the Origins of Public Information', in Francisco Bethencourt and Florike Egmond (eds.), Cultural Exchange in Early Modern Europe. Vol. III (Cambridge: Cambridge University Press, 2007), pp. 33-52. For Germany and a transnational approach see Katrin Keller and Paola Molino (eds.), Die Fuggerzeitungen im Kontext: Zeitungssammlungen im Alten Reich und in Italien (Vienna: Böhlau Verlag, 2015).

36 Martin Welke, 'Vom Elend der pressehistorischen Forschung in Deutschland. Dargestellt am Beispiel des Wolfenbütteler "Aviso"', in Volker Bauer and Holger Böning (eds.), Die Entstehung des Zeitungswesens. Ein neues Medium und seine Folgen für das Kommunikationssystem der Frühen Neuzeit (Bremen: Edition Lumière, 2011), pp. 151-152. 
knew about its content. The Aviso Relation oder Zeitung was meant to circulate among court associates outside Wolfenbüttel. Most, presumably, were distributed within the Duchy. Every week from 16o9 until at least 1615, privy councillor Erich Klack sent copies to the burgomaster of Salzwedel. ${ }^{37}$ Other copies of the paper were owned by Heinrich Albrecht von Gadenstedt, another Wolfenbüttel councillor. ${ }^{38}$ But the newspaper also ended up beyond the ducal territory. Martin Bütemeister, secretary of the legal court, regularly sent copies of the newspaper to Curt von Steinberg, a relative of the Görtz-Wrisberg family. This family of lower gentry resided outside the Duchy of Braunschweig-Wolfenbüttel and we can assume that this was not a singular case in which the newspaper found its way to readers outside the domain of the dukes at Wolfenbüttel.

Henry Julius' first and perhaps only goal with the newspaper was to facilitate the flow of information within his duchy. He had certainly felt a sense of how important it was for the functional elites in his duchy to stay abreast of the latest news. In contrast to Formica's newspaper then, the Aviso Relation served no ideological purpose, neither did it strive to convey a positive image of the duke. The newspaper was meant for local distribution and the duke had no need to win the allegiance and support of the readers in the administration of the duchy.

We can begin to get a sense of the nature of reporting in the Wolfenbüttel newspaper when we consider how von Söhne obtained the news content: the reports contained in the Aviso Relation oder Zeitung in all likelihood came from a commercial newsletter service based in Augsburg that also provided other courts and subscribers with a regular news digest. ${ }^{39}$ Neither von Söhne nor a ducal editor seemed to have tampered with the original text in any way save for some minor redactions concerning language and spelling.

The fate of the newspaper within the duchy of Braunschweig-Wolfenbüttel remains largely obscure. After Julius Adolph von Söhne died in 1616, his widow continued to print the newspaper before the workshop was eventually taken over by Elias Holwein in the same year. ${ }^{40}$ Ten years later, Holwein moved to

37 Behringer, Im Zeichen des Merkur, p. 366.

38 Wilhelm Hartmann, 'Wolfenbüttel als Druckort des "Aviso", der ältesten periodisch gedruckten Zeitung', Niedersächsisches Jahrbuch, 31 (1959), pp. 275-276.

39 Welke, Vom Elend der pressehistorischen Forschung in Deutschland, pp. 151-152. On the mechanics of news transmission in these newsletter centres see Wolf-Dieter Otte, 'Johann Martin Hirt und die Augsburger Agentur 1647-1661', in Jochen Brüning and Friedrich Niewöhner (eds.), Augsburg in der Frühen Neuzeit. Beiträge zu einem Forschungsprogramm (Berlin: Akademie-Verlag, 1995), pp. 39-118.

Reske, Die Buchdrucker, pp. 1017-1018. 
Celle, but maintained a workshop in Wolfenbüttel from which he printed mainly official editions for Duke Frederick Ulrich. The last known issue of the Aviso Relation oder Zeitung dates from 3 April $1624 .{ }^{41}$ Since seventeenth-century newspapers have suffered considerably high attrition rates, it is probable that the Aviso Relation oder Zeitung continued for some time after 1624 .

As in many other cases, the new medium of the printed newspaper did not replace established media in seventeenth-century Germany. Newspapers, whether printed by order of a duke, as was the case in Wolfenbüttel, or received in conjunction with diplomatic letters, did not become the sole purveyor of news. ${ }^{42}$ Augustus the Younger, second degree successor of Duke Henry Julius inherited and maintained an extensive network of correspondents across Europe who regularly sent him news from their respective places. An account drawn up in 1666 revealed that he sent 1700 thaler per year to his correspondents across Germany and Europe. ${ }^{43}$ This was a considerable sum and his successors sought to reduce the cost of newsgathering.

The Aviso Relation oder Zeitung was an addition to the information network put in place to facilitate the exchange of news within the duchy. Printing the weekly issues did not seem to have enjoyed the greatest priority at the court and in the workshop. Evidence suggests that the newspaper occasionally appeared on different days of the week in Wolfenbüttel. ${ }^{44}$ This was a stark contrast to the periodicals published by printers with no association to governmental bodies. Their reputation as reliable purveyor of newsprint was tied to their ability to deliver regularly. For instance, some of the periodicals produced in Frankfurt and Hamburg were distributed across the entire Holy Roman Empire. In order to reach their readers in time, their printers needed to deliver the copies at set times to the postal offices from which they would be distributed further

41 Behringer speculates that the newspaper was discontinued in 1627 after a failed Imperial attempt to besiege the city had resulted in the destruction of Holwein's workshop. However, he seems to have re-established himself fairly quickly as he printed no fewer than 16 editions in 1628 , two more than in 1626 , the year preceding the siege. See Behringer, Im Zeichen des Merkur, p. 361.

42 On the practices of courtly information see Ina Timmermann, "Nachdem unns itzo abermahls beyliegende Zeittungen zue kommen". Höfisches Nachrichtenwesen zwischen geschriebener und gedruckter Zeitung am Beispiel hessischer Landgrafen am Ende des 16. und zu Beginn des 17. Jahrhunderts. Dokumente aus dem Hessischen Staatsarchiv Marburg', in Astrid Blome (ed.), Zeitung, Zeitschrift, Intelligenzblatt und Kalender. Beiträge zur historischen Presseforschung (Bremen: Edition Lumière, 2000), pp. 137-159.

43 Elger Blühm, 'Die deutschen Fürstenhöfe des 17. Jahrhunderts und die Presse', in August Buck, Georg Kauffmann, Blake Lee Spahr and Conrad Wiedemann (eds.), Europäische Hofkultur im 16. und 17. Jahrhundert. Vol. 3 (Hamburg: Dr. Ernst Hauswedell, 1981), p. 595.

Behringer, Im Zeichen des Merkur, pp. 135-158. 
afield by stagecoach, carrier or barge. These printers had to make sure that the copies that were meant to be sent further afield were ready at the time when stagecoaches or barges left the city. If they failed to print in time, the copies reached their intended readers with some delay that would surely have caused consternation.

\section{Conclusion}

Of the vast majority of the 109 German-language newspaper titles published between 1605 and 1650 that we can still trace to this day, few had such close ties to the authorities as the Aviso Relation oder Zeitung and the Ordentliche Postzeittungen. The Viennese newspaper represented an outstanding and in many ways unique case of imperial propaganda furthering the agenda of the emperor. Readers undoubtedly sensed the strong pro-Habsburg bias of the Ordentliche Postzeittungen, and whether or not the periodical would have survived on the free market remains a question. As purveyors of news, periodicals owed their attractiveness to the reading public in part to their credibility and the relative absence of highly biased and partial reporting. The earliest days of the periodical can in many ways be considered a trial and error period and Duke Henry Julius experimented with the possibility of rapid news dissemination throughout his Duchy. While Ferdinand embraced the newspaper as a tool to construct his public persona as well as shape and maintain his reputation, the Duke in Wolfenbüttel seems to have purely focussed on the practical aspects of the newspaper. The regional distribution of the Aviso Relation oder Zeitung did not inspire further efforts to spread the duke's reputation abroad. Seen in the wider context of German newspapers, these two newspapers seem to have been outriders. Elsewhere, the relative independence of newspapers contributed in no small part to the long-term success of the genre. 